\title{
Effects of Thymus vulgaris and Mentha pulegium on colour, nutrients and peroxidation of meat in heat-stressed broilers
}

\author{
A. Pirmohamammadi ${ }^{1}$, M. Daneshyar ${ }^{1 \#}$, P. Farhoomand ${ }^{1}$, J. Aliakbarlu² \& F. Hamian ${ }^{2}$ \\ ${ }^{1}$ Department of Animal Science, Faculty of Agriculture, Urmia University, Urmia, Iran \\ ${ }^{2}$ Department of Food Hygiene and Quality Control, Faculty of Veterinary Medicine, Urmia University, \\ Urmia, Iran
}

(Received 14 August 2015; Accepted 8 February 2016; First published online 28 August 2016)

\author{
Copyright resides with the authors in terms of the Creative Commons Attribution 2.5 South African Licence. \\ See: http://creativecommons.org/licenses/by/2.5/za \\ Condition of use: The user may copy, distribute, transmit and adapt the work, but must recognise the authors and the South African \\ Journal of Animal Science.
}

\begin{abstract}
This study was designed to investigate the effects of Thymus vulgaris (thyme) and Mentha pulegium (mentha) powders on meat colour, nutrient composition and malondialdehyde (MDA) where broiler chickens were under heat stress. Two hundred one-day-old male chicks were used in a completely randomized design with four treatments and five replicates each (10 birds per replication). Treatments were the control diet, $0.5 \%$ mentha, $0.5 \%$ thyme and $0.5 \%$ mixture of the two plants. The results showed no effect of dietary supplements on thigh meat redness and yellowness. Both plant products diminished the thigh lightness significantly compared with the control. No significant differences between treatments were observed for the ash, ether extract and crude protein content of the thigh muscle. Supplementation of thyme and mentha separately or together increased the moisture of the thigh muscle significantly, compared with the control. The combination of the plant products resulted in a higher thigh $\mathrm{pH}$ and significantly lower malondialdehyde (MDA) concentration in the thigh muscle compared with the control. In conclusion, dietary supplementation of thyme and mentha separately or in combination improved the meat quality of broiler chickens under heat stress through decreasing the MDA concentration and increasing the $\mathrm{pH}$ and moisture content of the thigh muscle.
\end{abstract}

Keywords: Lightness, malondialdehyde, moisture, $\mathrm{pH}$, redness

\#Correspondence author: m.daneshyar@urmia.ac.ir or daneshyar_mohsen@yahoo.com

\section{Introduction}

High ambient temperature is a major problem in many parts of the world, especially in summer (Aksit et al., 2006). Exposure to high temperatures has been recorded as causing undesirable changes in the meat quality of broilers (Aksit et al., 2006). It has been reported that environmental stress and subsequent oxidative stress reduce the functional properties of muscle proteins and unbalance the antioxidant status of birds (Sacchetti et al., 2005). Heat stress during rearing is also one of the prominent ante mortem stressors, which results in a faster decline in $\mathrm{pH}$ and pale colour in breast meat in birds (Aksit et al., 2006). The higher lightness (L) during the summer was observed by Mc Curdy (1996) in turkey breast meat. Petracci et al. (2004) compared the breast muscle of broilers in summer and winter, and reported the higher lightness of meat for summer-reared broilers and lower redness (a) and yellowness (b) of meat for winter-reared ones. Lipid oxidation is a major cause of deterioration of muscle quality, which can directly affect the quality characteristics of flavour, colour, tissue, nutritional value and health in meat (Sharbati et al., 2015). Recently, the use of plant extracts as natural antioxidants has increased owing to restrictions on the use of synthetic materials. Natural antioxidants are biologically important protective cellular components (such as DNA, proteins, lipids and membranes) against reactive oxygen species, and have beneficial effects on human health (Tanabe et al., 2002). Plant extracts are capable of neutralizing free radicals and preventing oxidation of unsaturated fatty acids (Sacchetti et al., 2005). Garden thyme (Thymus vulgaris L.) belongs to the mint family (Lamiaceae). The origin of this plant is the Mediterranean region, the north of America and some parts of Asia (Stahl-Biskup \& Saez, 2002). Thyme is a short wooden perennial grey coloured plant with a C3 metabolism system, which is $30-50 \mathrm{~cm}$ tall, depending the climate of the growth region (Stahl-Biskup \& Saez, 2002). Thyme volatile phenolic oil has been reported to be among the top 10 essential oils, showing antibacterial, antimycotic, antioxidative, natural food preservative and anti-ageing properties (Naghdi Bhadi et al., 2004). Thymol and carvacrol are the major compounds of garden thyme (Chen et al., 2008). 
Antioxidant effects of various combinations of these plants have been demonstrated in several studies. Bolukbasi et al. (2006) reported that carvacrol and thymol could be responsible for the antioxidant effect of thyme. These researches indicated that the antioxidant capacity of thyme oil is more than that of vitamin $\mathrm{E}$ in thigh meat. Bolukbasi et al. (2006) reported that thyme oil (200 mg/kg) could reduce the thiobarbituric acid reactive substances (TBARS) of thigh and breast after slaughter and increase the weight gain in broilers. Adding powdered thyme to the meat of broilers causes lipid peroxidation stalling (Onibi, 2003).

Mentha is another medicinal plant, which belongs to the Labiatae family and includes 20 species that can be found all over the world. Mentha pulegium L. is one of the mentha species, commonly known as pennyroyal. It is native to Europe, North Africa, Asia Minor and the Near East (Mahdavi et al., 2013). The flowering aerial parts of $M$. pulegium were traditionally used for their antimicrobial properties in the treatment of cold, sinusitis, cholera, food poisonings, bronchitis and tuberculosis (Goordazi \& Nanekarani, 2014). Three chemotypes of $M$. pulegium with major oil components are pulegone, piperitenone and piperitone and isomenthone/neoisomenthol (Cook et al., 2007). A mixture of O. vulgare (1\%), M. pulegium (0.5\%) and Mentha piperita L. $(0.5 \%)$ has improved the carcass quality, weight gain, carcass efficiency and abdominal fat in broilers (Hernandez et al., 2004). Some research has been conducted on performance (above), but there is no report on the effects of these two plant products on the meat quality of broiler chickens. Hence the present research was conducted to reveal the effect of $T$. vulgaris and $M$. pulegium powders on quality, nutrient composition and meat colour of broiler chickens under heat stress.

\section{Materials and Methods}

Two hundred day-old male broiler chicks (Ross 308) were used in this experiment. All the birds were housed in 20 pens $\left(1 \mathrm{~m}^{2}\right)$ of 10 each, and five replicate pens were allocated to each treatment. Continuous light was used in the house. All the birds were fed the same starter (from day 1 to day 10 of age) and grower (from day 11 to day 24) diets in mash form, but they received the different finisher diets (from days 25 to 42 ) (Table 1). All the experimental treatments were under heat stress and birds were fed the control diet (without plant supplements), $0.5 \%$ T. vulgaris, $0.5 \%$ M. pulegium and a blend of $T$. vulgaris and M. pulegium (0.25\% of each). It has been stated that $0.5 \%$ of M. pulegium (Nobakht et al., 2011) and T. vulgaris (Rezaei et al., 2014) are enough to improve the performance in broiler chickens; consequently, such levels were used in the current experiment. The method of Yalcin et al. (2009) was used to induce the heat stress with some modifications ( $32{ }^{\circ} \mathrm{C}$ as cyclic from 9:00 to 17:00). The total phenolic compounds of mentha and thyme were $12.6 \mathrm{mg} / \mathrm{g}$ and $28.5 \mathrm{mg} / \mathrm{g}$ dry weight, respectively. The colorimetric method of Folin-Ciocalteu reagent, as explained by Daneshyar et al. (2012; 2011), was used to determine phenolic compounds. First, $1 \mathrm{~g}$ dried plant tissue was extracted with $10 \mathrm{~mL} 80 \%$ methanol. For total phenol measurements, $0.5 \mathrm{~mL}$ of the extract, gallic acid (as the standard), Folin (diluted with water in the ratio $1: 10$ ) and $4 \mathrm{~mL}$ of sodium carbonate (1 M) solution were mixed and allowed to stand at room temperature for 15 minutes. Standards were prepared with concentrations of $0,25,50,100,250$ and $500 \mathrm{mg} / \mathrm{mL}$, and uptake of the samples was measured at a wavelength of $765 \mathrm{~nm}$. Ultimately total phenols were expressed as $\mathrm{mg} / \mathrm{g}$ dry weight of the plant sample. The experimental diets were used during the finisher period (from day 25 to 42 of age) and under the heat-stress condition. Average ambient relative humidity inside the house was $45 \%$. At the end of the experiment (week 6), one chicken from each replicate pen (five per treatment) was selected randomly, marked and slaughtered. Two pieces of meat from each left thigh were removed to determine thigh meat indices. One piece was used for proximate analysis of dry matter (DM), crude protein (CP), ether extract (EE) and crude ash content. The other was transferred to the laboratory to check meat colour. The samples were collected in plastic trays, weighed and stored in airtight plastic bags in a freezer $\left(-20^{\circ} \mathrm{C}\right)$ until they were required for analysis. They were then homogenized with a blender, and analysed.

The thiobarbituric acid reactive substances (TBARS) method was used to determine malondialdehyde (MDA) concentration in thigh meat. The $\mathrm{pH}$ of thigh meat was measured with a digital $\mathrm{pH}$ meter (TitroLine Easy, Schott Instruments, Mainz, Germany) after homogenization in distilled water. The DM contents of thigh samples were determined by oven-drying at $105^{\circ} \mathrm{C}$ for $18 \mathrm{~h}$. The EE content of thigh samples was obtained by the Soxhlet extraction method, using anhydrous diethyl ether. The Kjeldahl method was used to analyse the total nitrogen content of thigh samples, and CP was expressed as nitrogen multiplied by 6.25. Meat moisture was determined with the vacuum oven method, according to the Association of Official Analytical Chemists (AOAC, 1999). The ground meat samples were dried for 48 hours in a vacuum-oven (23 kPa) at 98 ${ }^{\circ} \mathrm{C}$ and cooled to room temperature in a desiccator prior to taking final weights. The crude ash content was determined after heating the samples in a muffle furnace at $550{ }^{\circ} \mathrm{C}$ for 16 hours. Three parameters of meat colour, including lightness (L), redness (a) and yellowness (b) values were determined with a Minolta (CR100) Chroma Meter (Norouzi et al., 2014; Sharbati et al., 2015). The data were analysed based on a completely randomized design using the general linear model procedure of SAS (2002). When treatment 
means were significant $(P<0.05)$, the Duncan multiple range test was used to separate the means. The experimental protocols were reviewed and approved by the Animal Care Committee of Urmia University.

Table 1 Ingredient and nutrient composition of experimental diets

\begin{tabular}{|c|c|c|c|}
\hline & Starter, 0 - $10 \mathrm{~d}$ & Grower, 11 - 24 d & Finisher, 25 - 42 d \\
\hline \multicolumn{4}{|l|}{ Ingredients, $\%$} \\
\hline Maize & 32.91 & 34.55 & 38.66 \\
\hline Wheat & 20.00 & 25.00 & 25.00 \\
\hline Soybean meal & 39.35 & 33.50 & 28.35 \\
\hline Soybean oil & 3 & 2.80 & 3.18 \\
\hline Dicalcium phosphate & 2.10 & 2.15 & 2.15 \\
\hline Lime stone & 1.10 & 0.86 & 0.86 \\
\hline Lysine & 0.29 & 0.22 & 0.20 \\
\hline DL-methionine & 0.38 & 0.08 & 0.13 \\
\hline Vitamin-mineral mix* & 0.5 & 0.5 & 0.5 \\
\hline Sodium chloride & 0.37 & 0.34 & 0.34 \\
\hline Sand $^{\#}$ & - & - & 0.5 \\
\hline Total & 100 & 100 & 100 \\
\hline \multicolumn{4}{|l|}{ Calculated analysis in $\mathrm{g} / \mathrm{kg}$} \\
\hline Dry matter & 859.9 & 861.9 & 858.3 \\
\hline Metabolizable energy, MJ/kg & 11.97 & 12.23 & 12.48 \\
\hline Crude protein & 219.9 & 200.0 & 179.9 \\
\hline Fat & 49.3 & 48.3 & 53.3 \\
\hline Fibre & 39.6 & 37.0 & 33.3 \\
\hline Calcium & 10.0 & 9.00 & 8.90 \\
\hline Available phosphorus & 4.50 & 4.50 & 4.40 \\
\hline Chloride & 3.30 & 3.00 & 2.90 \\
\hline Sodium & 1.60 & 1.50 & 1.50 \\
\hline Methionine & 7.00 & 3.80 & 3.10 \\
\hline Lysine & 14.3 & 12.40 & 10.90 \\
\hline Arginine & 15.30 & 13.70 & 12.20 \\
\hline Methionine + cysteine & 10.70 & 7.30 & 7.30 \\
\hline Tryptophan & 2.90 & 2.60 & 2.30 \\
\hline Tyrosine & 9.80 & 8.90 & 8.10 \\
\hline Threonine & 8.50 & 7.70 & 6.90 \\
\hline
\end{tabular}

* Supplied per kilogram of diet: Vitamin A, $9000 \mathrm{U}$; vitamin $\mathrm{D}_{3}, 2000 \mathrm{U}$; vitamin $\mathrm{E}, 18 \mathrm{U}$; vitamin $\mathrm{B}_{12}$, 0.15 mg; riboflavin, $6.6 \mathrm{mg}$; calcium pantothenate, $10 \mathrm{mg}$; niacin, $30 \mathrm{mg}$; choline, $500 \mathrm{mg}$; biotin, $0.1 \mathrm{mg}$; thiamine, $1.8 \mathrm{mg}$; pyridoxine, $3 \mathrm{mg}$; folic acid, $1 \mathrm{mg}$; vitamin $\mathrm{K}_{3}, 2$ mg; antioxidant (Ethoxyquin), $100 \mathrm{mg}$; zinc, 50 mg; manganese oxide, $100 \mathrm{mg}$; Cu, $10 \mathrm{mg}$; $\mathrm{Fe}, 50 \mathrm{mg} ; \mathrm{l}, 1 \mathrm{mg}$; Se, $0.2 \mathrm{mg}$.

\# Different levels of $T$. vulgaris L. and M. pulegium powder or a blend of the two were replaced with sand in the diets at finisher. The finisher diet was fed during the final study.

\section{Results and Discussion}

The effects of dietary supplementation of thyme and mentha powders on meat colour parameters (lightness, redness and yellowness) at 42 days of age are shown in Table 2. No effect of either supplement was observed on thigh meat redness and yellowness $(P>0.05)$. Dietary supplementation of both plants diminished the thigh lightness compared with the control $(P<0.05)$. Furthermore, the combination of thyme 
and mentha decreased thigh meat lightness numerically. The lower lightness (L) of thigh meat was observed in dietary supplementation of the two plants separately or in combination. It is accepted that heat stress stimulates the glycolysis process and consequently decreases the thigh pH quickly and hence causes the pale meat (Remignon et al., 2006). But thyme and mentha powders prevented thigh paleness in the current experiment. Although no research has been done on the effects of thyme or mentha on meat quality in broilers under heat stress, the reduced meat lightness $(\mathrm{L})$ of broiler chickens by thyme and mentha may have two reasons. The antioxidant properties of these plants may be the first reason (Hirasa \& Takemasa, 1998; Tepe et al., 2006). Antioxidants retard or inhibit the oxidation of substances through initiation or propagation of oxidizing chain reactions. Consequently, natural antioxidants can protect the biologically important cellular components from oxidative processes caused by reactive oxygen species (ROS) (Velasco \& Williams, 2011). These plants are sources of natural antioxidants (Nakatani, 1992; Gonçalves et al., 2009), which can improve meat shelf-life and quality mainly by retarding lipid oxidation and microbial growth (Velasco \& Williams, 2011). Heat stress reduced the $\mathrm{pH}$ in the current experiment, which was followed by a pale colour of meat. The second possible reason for reduced meat lightness could be related to the ability of thyme and mentha powders to maintain acidity, prevent a loss in $\mathrm{pH}$, and hence prevent meat colour changes. Yang \& Chen (1993) reported increased redness and yellowness in ground chicken meat with low pH. Meat colour has been reported to be the most important factor of meat quality assessments by consumers and is related to meat freshness (Velasco \& Williams, 2011). In the same way, Chen et al. (2008) indicated that dietary garlic increased $\mathrm{pH}$ of in pig meat.

Table 2 Effects of dietary supplementation of thyme and mentha powders on meat colour indices of broilers under heat stress at 42 days of age

\begin{tabular}{lccc}
\hline Treatments & Lightness $(\mathrm{L})$ & Redness $(\mathbf{a})$ & Yellowness (b) \\
\hline $\mathrm{H}$ & $40.48^{\mathrm{a}}$ & 5.46 & 6.67 \\
$\mathrm{~T}$ & $38.22^{\mathrm{b}}$ & 5.10 & 6.20 \\
$\mathrm{M}$ & $37.57^{\mathrm{b}}$ & 5.62 & 5.58 \\
$\mathrm{TM}$ & $39.50^{\mathrm{ab}}$ & 5.46 & 6.11 \\
Pooled SEM & 0.44 & 0.18 & 0.31 \\
P-value & 0.03 & 0.81 & 0.66
\end{tabular}

\footnotetext{
${ }^{\mathrm{a}-\mathrm{b}}$ Means within each column with different superscripts are significantly different $(P<0.05)$.

$\mathrm{H}$ : heat stressed; M: heat stress + mentha; $\mathrm{T}$ : heat stress + thyme; TM: heat stress + mentha + thyme.
}

Changes in meat colour are due to oxidation of red oxymyoglobin to metmyoglobin (MMG), which gives meat an unattractive brown colour. Some reports demonstrated that natural antioxidants could postpone meat colour loss by extending the red colour $\left(a^{*}\right)$ and delaying MMG formation (Velasco \& Williams, 2011). Although the authors observed lowered lightness by the phytogenic supplements in the recent study, inconsistent results have been reported by different phytogenic plants. For example, Cornforth (1994) and Carpenter et al. (2007) observed no changes of $L^{*}, b^{*}$ and $a^{*}$ indices of raw pork patties from grape seed and bearberry extracts. Similarly, Lopez-Bote et al. (1998) detected no effects of oregano oil (1\%) on fresh chicken breast meat. The use of oral garlic in the diet of pigs increased the $\mathrm{pH}$, and reduced the $\mathrm{L}, \mathrm{a}^{*}, \mathrm{~b}^{*}$ of meat (Onibi, 2003). Using extracts of rosemary and sage reduced the lipid oxidation and cholesterol concentration of broiler meat during storage for nine days (Debut et al., 2003). In a study to evaluate the quality of broiler meat with green tea extract $(0.1$ and $0.2 \mathrm{~g}$ per $\mathrm{kg})$, $\mathrm{a}^{*}$ and $\mathrm{b}^{*}$ were both increased by rosemary and sage extract supplementation. These discrepancies are because the researches and the current study used different plants.

The effects of dietary treatments on ash, fat, protein, moisture and $\mathrm{pH}$ of thigh meat of broilers under heat stress at 42 days of age are indicated in Table 3. There were no significant differences between the treatments in the levels of the ash, EE and CP of the thigh meat $(P>0.05)$. Dietary supplementation of thyme and mentha separately or in combination increased thigh moisture compared with the control $(P<0.05)$. Supplementation of thyme or mentha numerically increased the thigh $\mathrm{pH}$, but only the combination of the two caused significantly higher thigh $\mathrm{pH}(P<0.05)$. Furthermore, all the dietary supplements resulted in a lower thigh MDA concentration $(P<0.05)$ (Figure 1 ). It has been reported that heat stress reduces meat $\mathrm{pH}$ (Cornforth, 1994). Cornforth (2002) stated that meat with a high pH has a higher water-binding capacity. 
Oxidative free radicals can cause oxidation of cellular lipid, DNA, and carbohydrates, and consequently damage the function of normal cells (Bianchi \& Antunes, 1999). The combined use of antioxidants could reduce the effects of stress due to oxi-reduction properties, which may have an important role in free radical quenching and neutralization, in addition to improving meat organoleptic characteristics (taste, sight, smell and touch) and quality (Jem et al., 2008).

Table 3 Nutrient composition of thigh meat in broilers fed thyme and mentha powder under heat stress at 42 days old

\begin{tabular}{lccccc}
\hline Treatment $^{\mathbf{1}}$ & $\begin{array}{c}\text { Ash } \\
(\%)\end{array}$ & $\begin{array}{c}\text { Ether extract } \\
\text { (\%) }\end{array}$ & $\begin{array}{c}\text { Crude protein } \\
(\%)\end{array}$ & $\begin{array}{c}\text { Moisture } \\
(\%)\end{array}$ & pH \\
\hline H & & & 18.91 & $74.75^{\mathrm{b}}$ & $6.56^{\mathrm{b}}$ \\
$\mathrm{T}$ & 2.11 & 1.59 & 18.56 & $76.18^{\mathrm{a}}$ & $6.71^{\mathrm{ab}}$ \\
$\mathrm{M}$ & 2.01 & 1.78 & 18.22 & $76.01^{\mathrm{a}}$ & $6.59^{\mathrm{ab}}$ \\
$\mathrm{TM}$ & 2.10 & 1.75 & 18.63 & $76.49^{\mathrm{a}}$ & $6.74^{\mathrm{a}}$ \\
Pooled SEM & 2.09 & 1.70 & 0.10 & 0.23 & 0.93 \\
P-value & 0.02 & 0.03 & 0.13 & 0.04 & 0.04
\end{tabular}

${ }^{\mathrm{a}-\mathrm{b}}$ Means within each column with different superscripts are significantly different $(P<0.05)$.

$\mathrm{H}$ : heat stressed; M: heat stress + mentha; $\mathrm{T}$ : heat stress + thyme; TM: heat stress + mentha + thyme.

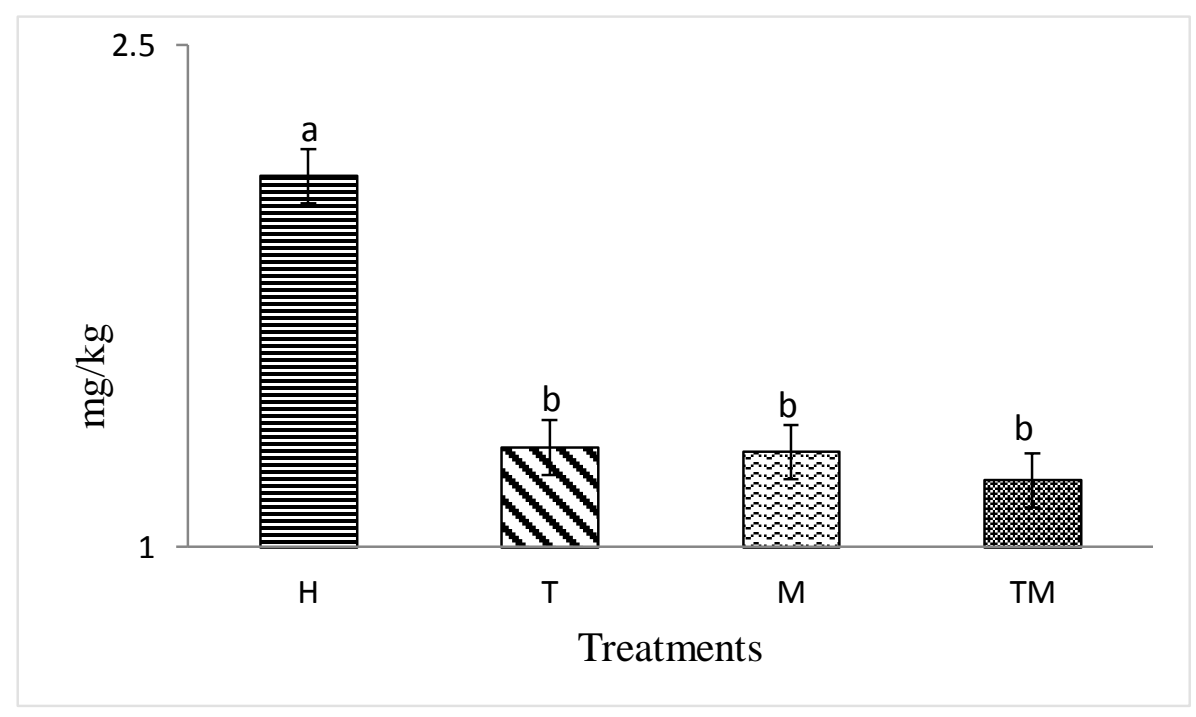

Figure 1 Thigh malondialdehyde (MDA) concentrations of broilers under heat stress $(H)$ and fed mentha $(M)$, thyme $(\mathrm{T})$ of the combination of the two $(\mathrm{TM})$ at day 42 of age (pooled SEM $=0.08, P<0.05$ ).

Thyme and mentha powders reduced the thigh meat MDA in the current experiment. This could be the consequence of antioxidant components of these plants. The positive effects of some plant extracts have been detected on lipid oxidation and MDA formation in different types of meats. Dietary supplementation with Forsythia suspensa extract has reduced the oxidative stress of broiler chickens under high ambient temperatures (Wang et al., 2008). Tanabe et al. (2002) added the methanolic extracts of certain herbs and spices and observed the positive effect of Zanthoxylum piperitum, Salvia officinalis and Zingiber officinale Rosc. extracts on pork lipid oxidation. In addition, dietary incorporation of oregano, rosemary, and sage essential oils can retard lipid oxidation (MDA formation) in meat during refrigerated and frozen storage (Bianchi \& Antunes, 1999).

\section{Conclusions}

According to the results of this study, dietary supplementation of thyme and mentha separately or together decreases the MDA and lightness and increases the $\mathrm{pH}$ and moisture of meat in heat-stressed chickens and hence can improve the meat quality during heat stress. 


\section{Acknowledgments}

The authors gratefully thank all staff of Animal Science Department, Faculty of Agriculture, University of Urmia for providing the necessary facilities during the research.

\section{Authors' contributions}

AP and MD designed, conducted the growth trial and collected the samples from the birds. JA and FH did the MDA determinations. PF was the co-principal investigator and MD was principal investigator of the research and approved the article before publication.

\section{Conflict of interest declaration}

The authors declare that they have no conflict of interest.

\section{References}

AOAC, 1999. Official Method of Analysis. (16th ed.). Association of Official Analytical Chemists, Maryland, USA.

Aksit, S., Yal cin, S., Ozkan, S., Metin, K. \& Özdemir, D., 2006. Effects of temperature during rearing and crating on stress parameters and meat quality of broilers. Poult. Sci. 85, 1867-1874.

Barbut, S., Sosnicki, A., Lonergan, A., Knapp, S., Ciobanu, T., Gatcliffe, D. \& Wilson, E., 2008. Progress in reducing the pale, soft and exudative (PSE) problem in pork and poultry meat. Meat Sci. 79, 46-63.

Bianchi, M. \& Antunes, G., 1999. Free radicals and the main dietary antioxidants Revista. Nutrição 12, 123-130.

Bolukbasi, C., Erhan, K. \& Ozkan, A., 2006. Effect of dietary thyme oil and vitamin E on growth, lipid oxidation, meat fatty acid composition and serum lipoproteins of broilers. S. Afr. J. Anim. Sci. 36, 189-196.

Carpenter, R., O'Grady, N., O'Callaghan, C., O'Brien, M. \& Kerry, P., 2007. Evaluation of the antioxidant potential of grape seed and bearberry extracts in raw and cooked pork. Meat Sci. 76, 604-610.

Chen, Y.J., Kim, I.H., Cho, J.H., Cho, H., Yoo, S., Wang, Q., Wang, Y. \& Huang, Y., 2008. Evaluation of dietary I-carnitine or garlic powder on growth performance, dry matter and nitrogen digestibilities, blood profiles and meat quality infinishing pigs. Anim. Feed Sci. Technol. 141, 141-152.

Cook, C.M., Maloupa, E., Kokkini, S. \& Lanaras, T., 2007. Differences between the inflorescence, leaf and stem essential oils of wild Mentha pulegium plants from Zakynthos Greece. J. Essent. Oil Res. 19, 239-244.

Cornforth, D.P., 1994. Color and its importance. Quality attributes and their measurement. In: Meat, Poultry, and Fish Products. Eds: Pearson, A.M. \& Dutson, T.R., Chapman and Hall, London, UK. pp. 34-78.

Cornforth, D.P., 2002. Potential use of phytate as an antioxidant in cooked meats. Ch. 12, In: Food Phytates. Eds: Reddy, R. \& Sathe, S.K., CRC Press, Boca Raton. pp. 199-209.

Daneshyar, M., Alizadeh Ghandkanlo, M., Sabzi Bayeghra, F., Farhangpajhoh, F. \& Aghaei, M., 2011. Effects of dietary turmeric supplementation on plasma lipoproteins, meat quality and fatty acid composition in broilers. S. Afr. J. Anim. Sci. 41, 420-428.

Daneshyar, M., Kermanshahi, H. \& Golian, A., 2012. The effects of turmeric supplementation on antioxidant status, blood gas indices and mortality in broiler chickens with T3-induced ascites. Br. Poult. Sci. 53, 379-385.

Debut, M., Berri, C., Baeza, E., Sellier, N., Arnould, C., Guemene, D. \& Le Bihan-Duval, E., 2003. Variation of chicken technological meat quality in relation to genotype and preslaughter stress conditions. Poult. Sci. 82, 1829-1838.

Gonçalves, R.S., Battistin, A., Pauletti, G., Rota, L. \& Serafini, L., 2009. Antioxidant properties of essential oils from Mentha species evidenced by electrochemical methods. Rev. Br. Plant Med. 11, 372-382.

Hernandez, F., Madrid, J., Garcia, V., Orengo, J. \& Megias, M., 2004. Influence of two plant extracts on broilers performance, digestibility, and digestive organ size. Poult. Sci. 83, 169-174.

Hirasa, K. \& Takemasa, M., 1998. Spice Science and Technology. Marcel Dekker, New York.

Jem, P., Vieira, S.L., López, J., Reis, R.N., Barros, R., Furtado, F.V.F. \& Silva, P.X., 2008. Ascorbic acid and citric flavonoids for broilers under heat stress: Effects on performance and meat quality. Braz. J. Poult. Sci. 10, 125-130.

Lopez-Bote, J., Gray, J.I., Gomaa, E.A. \& Flegal, C., 1998. Effect of dietary administration of oil extracts from rosemary and sage on lipid oxidation in broiler meat. Br. Poult. Sci. 39, 235-240.

Mahdavi, S., Mehmannavaz, Y., Nobakht, A. \& Zakeri, A., 2013. The effects of different amounts of Mentha pulegium L. on immune system performance of broiler chickens. Int. Res. J. Appl. Bas. Sci. 4, 381-384.

Mc Curdy, D., Barbut, S. \& Quinton, M., 1996. Seasonal effect on pale soft exudative (PSE) occurrence in young turkey breast meat. Food Res. Int. 29, 363-366.

Mc Kee, R. \& Sams, R., 1997. The effect of seasonal heat stress on rigor development and the incidence of pale, exudative turkey meat. Poult. Sci. 76, 1616-1620.

Naghdi Badi, H., Yazdani, D., Mohammad Ali, S. \& Nazari, F., 2004. Effects of spacing and harvesting time on herbage yield and quality/quantity of oil in thyme, Thymus vulgaris L. Ind. Crops Prod. 19, 231-236.

Nakatani, N., 1992. Natural antioxidants from spices. In: Phenolic Compounds in Food and Their Effects on Health IIAntioxidants and Cancer Prevention. Eds: Huang, MT., Ho, Che Tang. \& Lee. \& Chang, Y., Am. Chem. Soc. Was. pp. 72-86.

Nobakht, A., Norani, J. \& Safamehr, A., 2011. The effects of different amounts of Mentha pulegium L. (pennyroyal) on performance, carcass traits, hematological and blood biochemical parameters of broilers. J. Med. Plants Res. 5, 3763-3768. 
Norouzi, E., Daneshyar, M., Farhoomand, P., Aliakbarlu, J. \& Hamian, F., 2014. Effect of zinc acetate and magnesium sulfate dietary supplementation on broiler thigh meat colour, nutrient composition and lipid peroxidation values under continuous heat stress condition. Ann. Anim. Sci. 14, 353-363.

Onibi, E., 2003. Evaluation of thyme as an antioxidant in broiler chicken meat, In: Nigerian Livestock: A gold Mine for Economic Growth and Food Security. Eds: Taiwo et al., Proc. 28th Annual Conf. Nig. Soc. Anim. Prod., Inst. Agric. Res., Tr. Ibad. Nig. pp. 61-64.

Peterson, J. \& Dwyer, J., 1998. Flavonoids: dietary occurrence and biochemical activity. Nutr. Res. 18, 1995-2018.

Petracci, M., Betti, M. \& Cavani, C., 2004. Color variation and characterization of broiler breast meat during processing in Italy. Poult. Sci. 83, 2085-2092.

Remignon, H., Molette, C., Babile, R. \& Fernandez, X., 2006. Current advances in proteomic analysis and its use for the resolution of poultry meat quality problems. Wrlds Poult. Sci. J. 62, 123-130.

Rezaei, M., Kalantar, M. \& Nasr, J., 2014. Thymus vulgaris L., glycyrrhiza glabra and combo enzyme in corn or barleybasal diets in broiler chickens. Int. J. Pl. Anim. Env. Sci. 4, 418-423.

Sacchetti, G., Maietti, S., Muzzoli, M., Scaglianti, M., Manfredini, S., Radice, M. \& Bruni, R., 2005. Comparative evaluation of 11 essential oils of different origin as functional antioxidants, antiradicals and antimicrobials in foods. Food Chem. 91, 621-632.

SAS, 2002. Statistical Analysis Systems Users Guide: Statistics. SAS Institute Inc., Cary, N.C., USA.

Sharbati, A., Daneshyar, M., Aghazadeh, A., Aliakbarlu, J. \& Hamian, F., 2015. Effects of Rhus coriaria on nutrient composition, thiobarbituric acid reactive substances and colour of thigh meat in heat-stressed broilers. S. Afr. J. Anim. Sci. 45, 49-55.

Stahl-Biskup, E. \& Saez, F., 2002. Thyme. Taylor and Francis, London, UK. pp. 20-42.

Tanabe, H., Yoshida, M. \& Tomita, N., 2002. Comparison of the antioxidant activities of 22 commonly culinary herbs and spices on the lipid oxidation of pork meat. Anim. Sci. J. 73, 389-393.

Tepe, B., Sokmen, M., Akpulat, A. \& Sokmen, A., 2006. Screening of the antioxidant potentials of six Salvia species from Turkey. Food Chem. 95, 200-204.

Velasco, V. \& Williams, P., 2011. Improving meat quality through natural antioxidants. Can. J. Agr. Res. 72, $313-322$.

Wang, L., Piao, X.L., Kim, S.W., Piao, X.S., Shen, Y.B. \& Lee, H., 2008. Effects of Forsythia suspensa extract on growth performance, nutrient digestibility, and antioxidant activities in broiler chickens under high ambient temperature. Poult. Sci. 87, 1287-1294.

Yang, C. \& Chen, C., 1993. Effects of refrigerated storage, pH adjustment, and marinade on color of raw and microwave cooked chicken meat. Poult. Sci. 72, 355-362. 